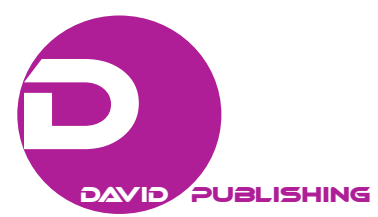

\title{
The Financial Barriers of SMEs in Albania and Their Impact on the Economic Development
}

\author{
Fatmira Kola, Erjon Sula \\ Tirana Metropolitan University, Tiranë, Albania \\ Mario Calabrese \\ University of Salerno, Salerno, Italy
}

\begin{abstract}
Small and medium enterprises (SMEs) represent a significant portion of gross domestic product (GDP) and are recognized as pillars of the economy in Albania. They are the first generators of employment and have a positive impact on revenue from taxes and fees. SMEs are the main bearer of new technology and innovation in the economic fields and the development and exchange of experiences between countries and cultures. The main problems facing the SMEs are administrative barriers, project financing, and lack of specialists in specific profiles. The fact in Albania needs too much work to be done to improve the high degree of informality. The financial system in Albania has not been confronted with a pure financial crisis. The system has had problems that stem from macroeconomic and microeconomic issues, such as fiscal problems, the existence of the informal market, lack of public knowledge about the financial market, and the impact of the international crisis.
\end{abstract}

Keywords: financial barriers, small and medium enterprises (SMEs), informality, gross domestic product (GDP), Albania

\section{Introduction}

Small and medium enterprises (SMEs) have an important role in the economy of Albania, because they provide the largest contribution to gross domestic product (GDP) and social life of the population. Development of the SMEs sector is considered to be one of the most efficient economies in transition, which generates sustainable economic growth, employment, and poverty reduction, not only in transition countries like Albania, but in the whole European economy (Johnson, Kaufmann, \& Shleifer, 1997). This is one of the reasons why the European Union has reviewed the definition of SMEs by creating facilities for these types of businesses. Twenty-five European countries that counted 23 million SMEs provide around 75 million jobs and represent $99 \%$ of enterprises (European Commission, 2005).

SMEs are seen as the main sources for the formation of entrepreneurial skills, innovation, and improvement of other macroeconomic factors.

This analysis will identify the financial barriers of SMEs in Albania and their impact on economic development.

Fatmira Kola, M.Sc. in international finance and risk management, Tirana Metropolitan University, Tiranë, Albania.

Erjon Sula, M.Sc. in management, Tirana Metropolitan University Tiranë, Albania.

Mario Calabrese, Ph.D. in management, Simas Lab, Department DISTRA, MIT, University of Salerno, Salerno, Italy.

Correspondence concerning this article should be addressed to Fatmira Kola, Tirana Metropolitan University, Tiranë, Albania.

E-mail: fatmirakola@gmail.com. 


\section{Methodology}

Methodologies used for this work have been divided into three phases:

- The first step consists in reviewing the literature regarding to the theme of the address, which includes the study of books, articles, and papers nationally and internationally;

- The second step includes data collection of publications of the Bank of Albania, Institute of Statistics, and the use of questionnaires and surveys of SMEs from some banks;

- The last step consists in the analysis of the data, which is structured on the logic of issues connected to the available resources, the problems and difficulties that currently exist in finding sources of funding for SMEs and their impact on the economic development.

\section{Macro-economic Situation}

Albania markets are considered to have a high growth potential in Balkan. Albania has been in the attention of European Union countries, most affected by the crisis and in particular the countries that are geographically connected to these two states, while having a strategic geographical location and a favorable climate to develop different activities.

Granting of candidate status for Albania in Europe is a very important step, as it increases trust towards institutions and the economy in general often named as informal and with a high degree of informality.

In Albania, the sectors with potential for development are: service sector, mineral industry, tourism, energy, and agribusiness, as agricultural land and climate are favorable situations for the development of all plants.

Lately, the economic growth has been positive, presenting a growing trend of GDP, presented as follows in Figure 1.

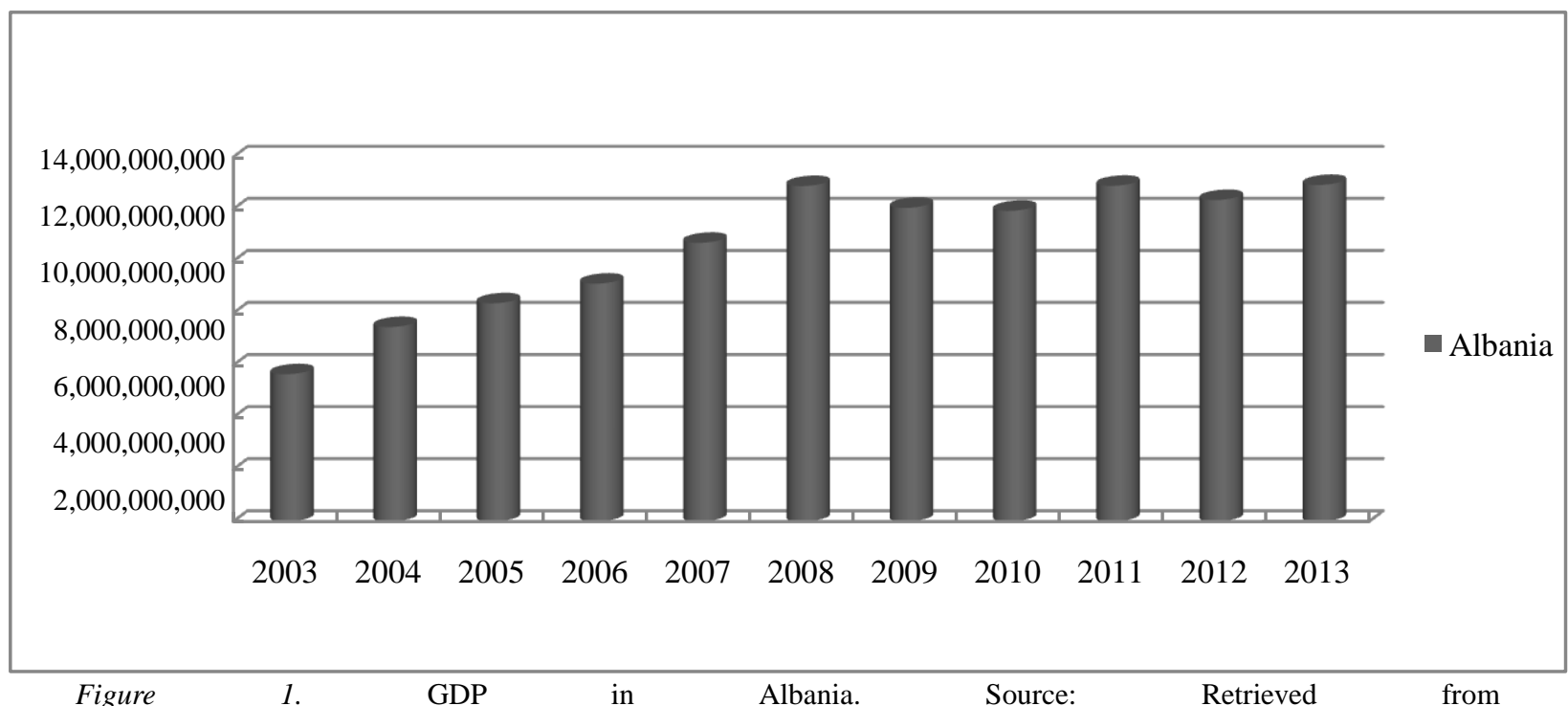

http://data.worldbank.org/indicator/NY.GDP.MKTP.CD/countries?display=default.

By the end of the de-stabilization period, as a result of the collapse of financial speculation in 1997, tax revenues as a percentage of GDP in Albania, has been a growing trend in the coming years, with the most pronounced increase until 2008. By January 1st, it became effective value added tax rate of $10 \%$, with the 
lowest in the region and Western Europe. The revenue collected to GDP ratio reached its highest level in 2008 by $9.8 \%$, year out it faced the effects of declining consumption and deepening the trade balance (flow of goods in foreign trade), as a result of the GDP.

The income tax structure in Albania is similar to what most countries call tax corporate income (corporate income tax). The essential difference is that with international practice or not being subject to income tax, Albania depends on business turnover rather than the legal form of the organization of business activity.

The first year of the global impact in the economy and financial crisis in Albanian, although less effect in the region, was 2009. The slower pace of economic growth was reflected in the ability to contribute to the fees and charges to individuals and businesses, both in terms of direct taxation (income) and indirect tax on it through the reduction of the consumption of goods and services (Lawrence \& Chad, 2007). According to the GDP in these countries, the emigrant remittances are of great importance, which due to financial crises are drastically declined recently.

\section{The Development in the SMEs Sectors}

According to the legislation of Albania, SMEs are defined as what it is in accordance with the following parameters (Table 1).

Table 1

SMEs Definition in Albania

\begin{tabular}{lcl}
\hline Enterprise size & Number of employees (Albania) & Annual turnover* (Albania) \\
\hline Micro & $1-5$ & $>10 \mathrm{mln}$ lek \\
Small & $6-20$ & $>80 \mathrm{mln}$ lek \\
Medium & $21-80$ & $>250 \mathrm{mln} \mathrm{lek}$ \\
\hline
\end{tabular}

Source: Retrieved from http://ligjet.info/shoqerite_tregtare/nmv/ligje/8957.

The elements which are defined by the size of these businesses are in compliance with European standards and stating the number of employees and annual turnover. The latter is a change from the European economic standards based on this country.

The economy in Albania is dominated by small-micro enterprises. In Albania, the bulk (69\%) are self-employed, while only large enterprises have 50 or more employs representing $1.3 \%$ of total enterprises, but their contribution to employment is very significant $(26.7 \%)$. About $52 \%$ of active enterprises are concentrated in the districts of Tirana and Durrës (Retrieved from http://www.instat.gov.al/al/publications.aspx). The industry and other services, such as education, health, and financial intermediaries, represent $76.5 \%$ of enterprises with 50 or more employees.

In 2013, according to the registry of enterprises, there are 111,083 enterprises that conduct economic activity.

These enterprises mainly operate in the following sectors: From 111,083 , a very considerable number of SMEs are estimated at 109,677. According to the data of the two countries, the statistics notice the sector of trade in goods and services which occupies the most important share of the economic activity (Figure 2).

Looking closely to the issues that businesses face, from 100 SMEs operating in the Albanian market, $80 \%$ of them operate in Tirana. In Figure 3 below, the active of SMEs by economic activity in Albania are represented. 


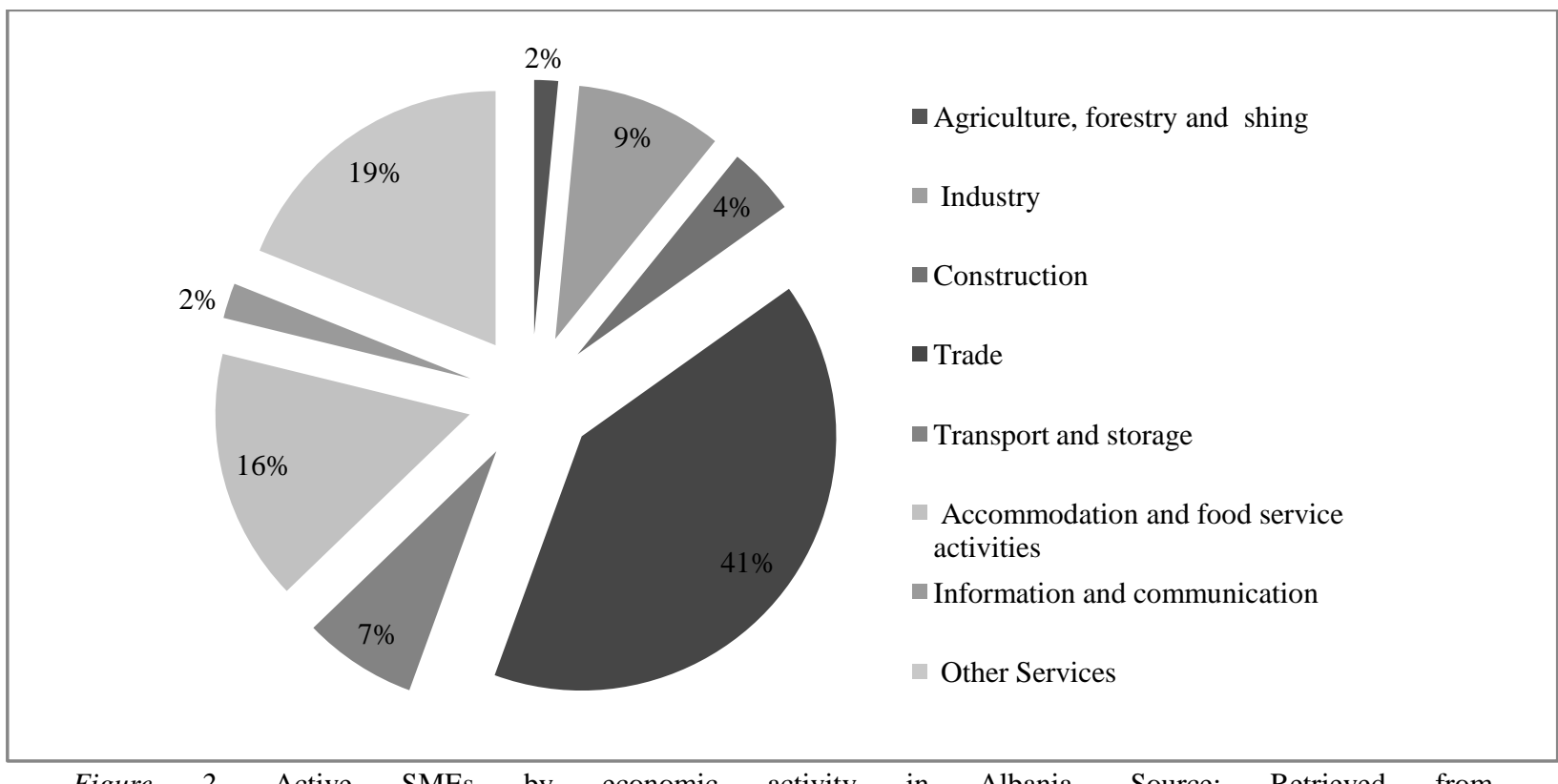

Figure 2. Active SMEs by economic activity in Albania. Source: Retrieved from http://www.instat.gov.al/al/figures/statistical-databases.aspx.

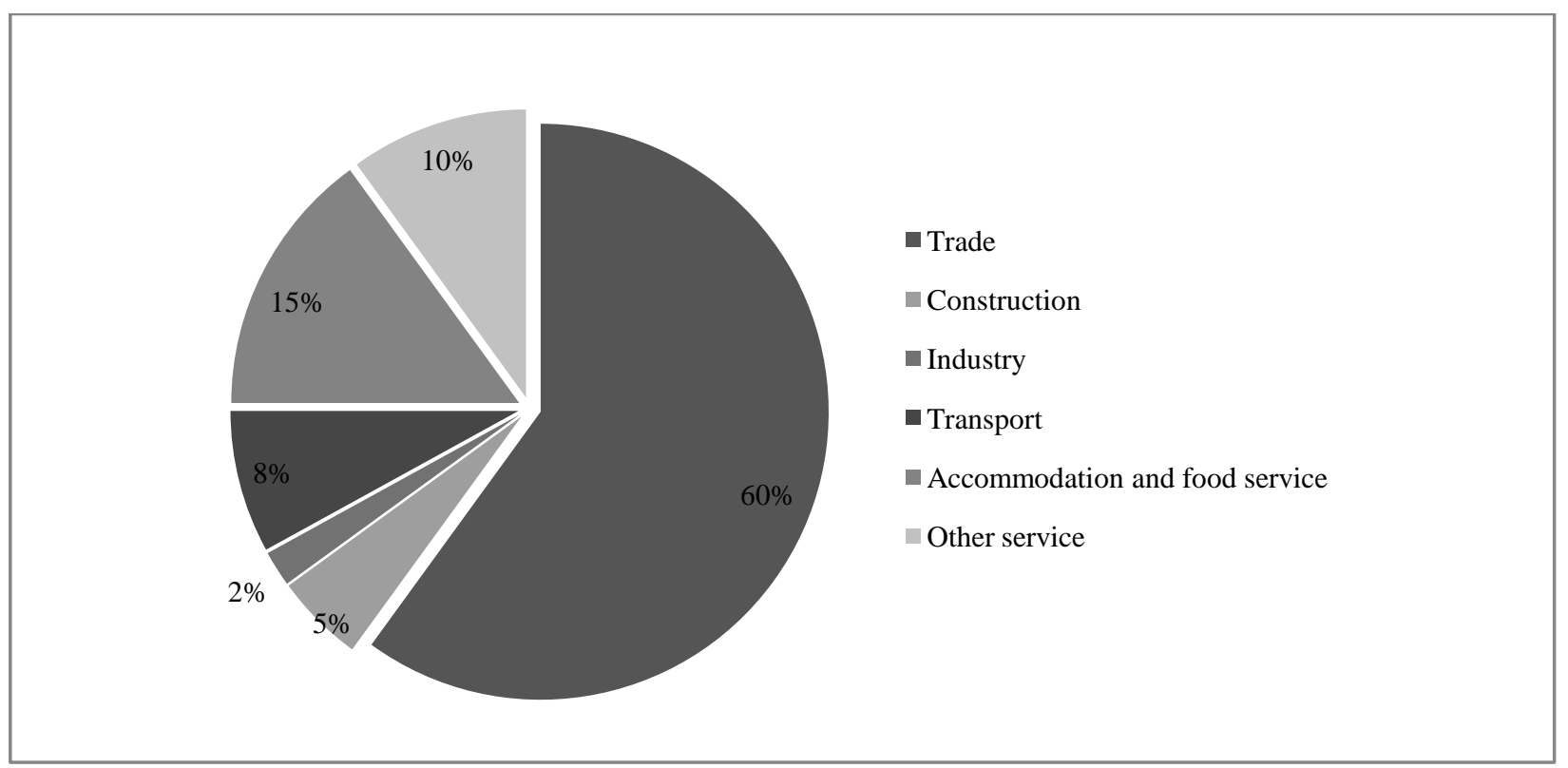

Figure 3. Active SMEs by study in Albania.

Based on various studies and the reports conducted in Albania by the respective institutes, also on the publications of the strategies of development pursued by the ministries of economy and trade of respective international institutions, the challenges facing SMEs encounters in Albania are: the informal economy, the protection of the legal system, problems in the right to property, and difficulties with obtaining construction permit.

In Figure 4 below, some of the main barriers in Albania in 2014 and 2015 are presented.

Although the level of financing SMEs has increased in the last few years, it is still considered insufficient 
to promote a rapid development of this sector. Also SMEs also face a lot of new difficulties obtaining loans from the banking sector, where the cost of the loan is relatively high. Bank requirements are not favorable to businesses, particularly the high level of $120 \%-150 \%$ collateral and high interest loan required for investment in machinery and equipment.

What is missing is supporting policies for freshly started businesses. There is a lack of alternative financial resources for SMEs as venture capital, innovation vouchers, and business angels. Despite the increase in the number of second-tier banks and the increase in banking competition, high interest loans remain high, creating a barrier for business investments. This type of contraction began in 2009 and continued to cause problems in the economic system.

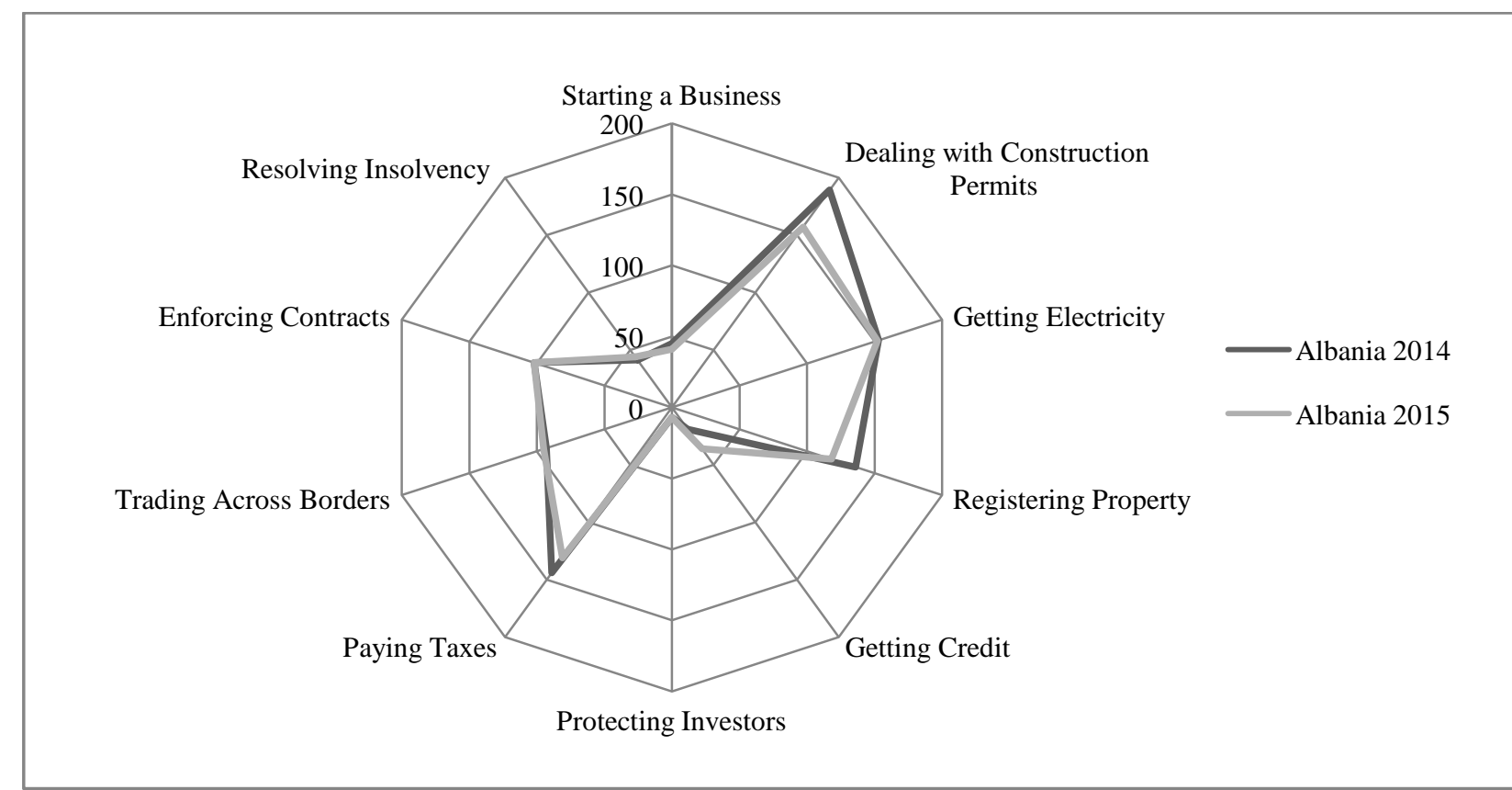

Figure 4. The business environment in Albania. Source: Retrieved from http://www.doingbusiness.org/data/exploreeconomies/ /media/giawb/doing\%20business/documents/profiles/country/ ALB.pdf?ver=2.

\section{Barriers to SMEs Financing}

The financial system in Albania has not been confronted with a pure financial crisis. The system has had problems that stem from macroeconomic and microeconomic issues, such as fiscal problems, the existence of the informal market, lack of public knowledge about the financial market, and the impact of the international crisis. The political climate in the country has been fed with this in moments of crisis in the banking system. The most prominent impact of the crisis has been on the level of deposits and investments.

To maintain the level of deposits (Retrieved from http://www.amf.gov.al/pdf/publikime2/raport/amf/405_ Raport\%20Vjetor\%202014.pdf), the Bank of Albania in cooperation with the Ministry of Finance and the Deposit Insurance Agency Bank, decided to increase the level of insured deposits of people in ALL 2,500,000 (EUR 20,000). After the financial crisis, many businesses displayed a lack of liquidity, which often forced to borrow in other banks to repay their obligations. To maintain the stability of Albania, bank credit created database with all the information on the exposures of each client, which gives the opportunity to have detailed 
information for every borrowers.

Conditions borrower must complete before the financial crisis were more favorable for them, mainly in the levels of collateral that banks should take into guarantee. This has negatively affected in the short term and prevents the increase of economy, as it has been the growth of problem loans. The problem (Retrieved from http://www.aab.al/documents/rp/AABRaportVjetor2013.pdf) of bad loans more than a phenomenon resulting massive focused on a handful of businesses, where more than half of the bad loans nationwide belong to only 35 companies or groups of companies trading which occupy about $52 \%$ of total loans the outstanding Albanian economy.

The entry of the foreign capital in the banking system of Albania is the highest in the region (Retrieved from http://www.bankofalbania.org/web/Raporti_Vjetor_2013_7066_1.php). According to some theories, the level of the competition would be expected to be high, but this has not fully happened, perhaps because foreign banks are used to high profits and may not be ready and driven to destroy this with aggressive behavior.

During the expansion of the economy, lending rates rise too high and significantly decrease, when the economy is in decline (Grinblatt, Hillier, \& Titman, 2011). With the onset of the global financial crisis and the bankruptcy of some of the strongest banks in the world, Albanian banks increased interest on loans and tightened lending standards. This resulted in many Albanian companies reducing their investments.

The data show that the crisis has affected:

- fall of remittance rates;

- fall of savings deposit rates;

- fall of export-import rates;

- weakening of appreciation against the euro and the US dollar;

- curbing bank lending, especially in foreign currency.

Economic growth is an important factor in the development of the capital market, as it leads to the creation of new markets and opportunities for businesses, which forces them to seek more funding to expand their economic activity.

Looking closely to the issues that face businesses under study 100 SMEs operating in the Albanian market, $80 \%$ operate in Tirana.

The analysis of completed questionnaires has been identified that financing of companies comes from three main sources:

- private saving: the banking system and auxiliary institutions;

- public savings: state;

- private foreign investment.

Financing difficulties of SMEs encounter at two levels:

- the domestic level: the inadequacy of self-financing (by companies dependency on banks, capital market shareholders) weak investment growth.

- the external level: financial market (difficulty of access and use of primary and secondary financial market), the banking system (in the form of loan short term loans, cash loans or guarantees), and the state (to finance productive investments, projects of common interest) and foreign aid in the form of loan.

The role of each of these sources in financing companies in Albania is assessed, according to the criteria (quantitative importance, cost, ease of access, and the ability to use the funds). Public assistance mainly obeys political motives, direct investment, and equity participation in conditioned by prospects of profitability. 
For loans, the determining factor is the ability of the refund. But the increase in the percentage of debt makes it more difficult to find foreign aid and investment volume to achieve.

The latter remains a widely used resource for companies, although there are high interest rates, due to the lack of other financing alternatives. Many Albanian companies have used bank loans to upgrade their technology.

Factors with the greatest impact on the tightening of lending criteria were current status and expected macro-economic, and sector-specific problems which operate businesses and loans.

Unless loan-taking is made more difficult, interest rates continue to remain high even after lowering the basic interest rate.

Foreign currency loans remain a requirement of Albanian companies, rather than loans in euro and other currencies. Factors leading companies to promote demand for foreign currency loans are the difference in interest rates and the source of income in foreign currency exchange rate trends.

Businesses in Albania continue to stay away from quotation on the exchange. The motives are as follows:

- failure to meet quality criteria for listing: Among these criteria for listing on the stock exchange, the low level of management and quality of financial reporting can be mentioned;

- type of business activity: Big business is concentrated in activities with rapid turnover of capital.

Businesses in Albania are organized in the form of limited liability companies as well as in the form of a joint stock at a low level. This is an indication of the tradition and culture of business development, which means that it is the more preferred form with one or few owners. According to the study, the most frequent reasons that negatively affect the development of the capital market are as follows:

- Weak financial culture administrators - staff administrators and staff of Albanian companies, have little or no knowledge of the capital market, financial instruments, and use of this market to finance their economic activity;

- The lack of genuine competition among companies within the respective sectors of the economy in those levels does not necessarily require large-scale financing of Albanian businesses through the stock exchange;

- Private sector demand continues to be negatively affected by low confidence of economic agents, the revenue slowdown, and relatively high conditions of funding. However, savings banks have increased significantly since then. These savings are invested more in the form of loans. Development of a successful capital market would help in creating and establishing trust, as to capital market institutions and to issuers of securities;

- Capital market development also depends on several factors that classify the economic-financial situation related to the company itself and the regulatory environment and stimulus.

According to information received from some second tier banks, it turns out that banks present obstacles to SMEs credit, because of their restrictive policies. Some commercial banks have expressed that even the SMEs are unable to absorb the amount needed for funding, deficiencies that may be mentioned here by the SMEs to attract funds for financing are:

- lack of preparation of clear and reliable business plans for the bank;

- lack of accounting information which should possess SMEs to hinder the process of pursuing the borrower liquid state;

- the level of confidence in local consultants which is too low, making the SMEs seek advice from external consultants. The cost of foreign consultation is too high. Consequently, SMEs do not last longer than the procedures for funding. 


\section{Conclusions}

For the medium term, Albanian companies will continue to extensively use the banking system to finance their activities. The latter remains a widely used resource for companies, although there are high interest rates, due to the lack of other financing alternatives. Bank loans are used by Albanian companies more for working capital, pointing out that low interest companies use the capital market to finance long-term projects and their sustainable growth in the future.

Leasing and factoring are still under developed and also dependent on the elimination of legal uncertainties. Albania should clarify the regulatory environment for financial leasing and its treatment regarding added tax value. In addition, there is a need to increase public awareness of leasing and factoring as financing options.

All companies surveyed have accounts in different banks of the second level. They use a lot of the banking system to make transfers within and outside the country. This shows an increase of the role of commercial banks in the life and activity of these companies. For foreign currency transactions as banks and companies which use an informal market (parallel), the informal market continues to be attractive.

In the relationship between the financial system and SMEs, the most important issues are:

- the interest rate on loans;

- the demand for collateral banks;

- bureaucracy of banks, the average time to obtain a loan varies from 15 to 25 days;

- high commissions bank.

Albanian companies in the medium term will continue to widely use the banking system to finance their activities, mainly through bank loans.

To eliminate financial barriers, the state and economic agents should take the following actions:

- transparent privatization of strategic companies;

- attracting more liquidity in the formal sector of the economy;

- promotion of possession rule securities at a larger scale by the public;

- creating and establishing trust, especially financial institutions and societies;

- promotion of Albania as a country with growing economic stability;

- attracting more foreign investment in Albania;

- development of institutions and long-term savings schemes;

\section{References}

Albanian Association of Banks. (2013). Annual report. Retrieved from http://www.aab.al/documents/rp/AABRaportVjetor2013.pdf

Albanian Statistics Institute. (2013). Report of statistical register of enterprises in 2013 . Retrieved from http://www.instat.gov.al/al/figures/statistical-databases.aspx

Albanian Statistics Institute. (2014). Report of statistical register of enterprises in 2014. Retrieved from http://www.instat.gov.al/al/publications.aspx

Assembly of the Republic in Albania. (2014). Laws of the Republic of Albania. Retrieved from http://ligjet.info/shoqerite_tregtare/nmv/ligje/8957

Bank of Albania. (2013). Annual report. Retrieved from http://www.bankofalbania.org/web/Raporti_Vjetor_2013_7066_1.php

European Commission. (2005). The new SME definition. User guide and model declaration. Retrieved from http://europa.eu.int/comm/enterprise/enterprise_policy/sme_definition/index_en.htm

Financial Supervisory Authority in Albania. (2014). Annual report. Retrieved from http://www.amf.gov.al/pdf/publikime2/raport/amf/405_Raport\%20Vjetor\%202014.pdf 
Grinblatt, M., Hillier, D., \& Titman, S. (2011). Financial market and corporate strategy. London: McGraw Hill.

Johnson, S., Kaufmann, D., \& Shleifer, A. (1997). The unofficial economy in transition. Retrieved from http://citeseerx.ist.psu.edu/viewdoc/download?doi=10.1.1.335.7671\&rep=rep1\&type=pdf

Lawrence, J. G., \& Chad, J. Z. (2007). Principles of managerial finance. Lakewood: Prentice Hall.

World Bank. (2014). World development indicators. http://data.worldbank.org/indicator/NY.GDP.MKTP.CD/countries?display=default

World Bank. (2015). Doing business in Albania. Retrieved from http://www.doingbusiness.org/data/exploreeconomies/ /media/giawb/doing\%20business/documents/profiles/country/ALB.p df? ver=2 